\title{
Effect of Metallothionein-III on Mercury-Induced Chemokine Gene Expression
}

\author{
Jin-Yong Lee ${ }^{1}$, Maki Tokumoto ${ }^{1}$, Gi-Wook Hwang ${ }^{2}$, Min-Seok Kim ${ }^{2,3}$, Tsutomu Takahashi ${ }^{2,4}$, \\ Akira Naganuma ${ }^{2}$, Minoru Yoshida ${ }^{5}$ and Masahiko Satoh ${ }^{1, *}$ \\ 1 Laboratory of Pharmaceutical Health Sciences, School of Pharmacy, Aichi Gakuin University, \\ 1-100 Kusumoto-cho, Chikusa-ku, Nagoya 464-8650, Japan; leejy@dpc.agu.ac.jp (J.-Y.L.); \\ maki@dpc.agu.ac.jp (M.T.) \\ 2 Laboratory of Molecular and Biochemical Toxicology, Graduate School of Pharmaceutical Sciences, \\ Tohoku University, Sendai 980-8578, Japan; gwhwang@m.tohoku.ac.jp (G.-W.H.); \\ assams7@naver.com (M.-S.K.); tsutomu@toyaku.ac.jp (T.T.); naganuma@tohoku.ac.jp (A.N.) \\ 3 Laboratory Animal Center, Daegu-Gyeongbuk Medical Innovation Foundation, Daegu 41061, Korea \\ 4 Department of Environmental Health, School of Pharmacy, Tokyo University of Pharmacy and Life Sciences, \\ 1432-1, Horinouchi, Hachioji, Tokyo 192-0392, Japan \\ 5 Faculty of Health and Medical Care, Hachinohe Gakuin University, 3-98 Mihono, Hachinohe 031-8588, \\ Japan; m2yosida@hachinohe-u.ac.jp \\ * Correspondence: masahiko@dpc.agu.ac.jp; Tel.: +81-52-757-6790; Fax: +81-52-757-6799
}

Received: 15 June 2018; Accepted: 7 August 2018; Published: 12 August 2018

\begin{abstract}
Mercury compounds are known to cause central nervous system disorders; however the detailed molecular mechanisms of their actions remain unclear. Methylmercury increases the expression of several chemokine genes, specifically in the brain, while metallothionein-III (MT-III) has a protective role against various brain diseases. In this study, we investigated the involvement of MT-III in chemokine gene expression changes in response to methylmercury and mercury vapor in the cerebrum and cerebellum of wild-type mice and MT-III null mice. No difference in mercury concentration was observed between the wild-type mice and MT-III null mice in any brain tissue examined. The expression of $\mathrm{Ccl} 3$ in the cerebrum and of $\mathrm{Cxcl10}$ in the cerebellum was increased by methylmercury in the MT-III null but not the wild-type mice. The expression of $\mathrm{Ccl} 7$ in the cerebellum was increased by mercury vapor in the MT-III null mice but not the wild-type mice. However, the expression of $\mathrm{Ccl12}$ and $\mathrm{Cxcl12}$ was increased in the cerebrum by methylmercury only in the wild-type mice and the expression of $\mathrm{Ccl} 3$ in the cerebellum was increased by mercury vapor only in the wild-type mice. These results indicate that MT-III does not affect mercury accumulation in the brain, but that it affects the expression of some chemokine genes in response to mercury compounds.
\end{abstract}

Keywords: methylmercury; mercury vapor; metallothionein-III; chemokine

\section{Introduction}

Several mercury compounds are considered hazardous, exerting mainly central nervous system (CNS) or renal damage [1-3]. Methylmercury is a pollutant that causes severe damage $[4,5]$, and accumulates in fish by bioaccumulation. Recent epidemiological investigations have shown that pregnant women who take up relatively large amounts of methylmercury are at higher risk of delivering children with developmental disorders [6,7]. Mercury vapor also produces neuronal damage, and the exposure of gold miners to high levels of mercury vapor through mercury amalgamation is a great concern in developing countries [8,9]. Furthermore, the exposure of children to mercury vapor has increased due to the use of mercury in amalgam to extract gold from ores [10]. Recently, it was reported that high concentrations of methylmercury were detected in grains yielded 
near a mercury mine in China [11]. These reports suggest that rice is a source of methylmercury exposure in the area. In addition, the median estimated methylmercury intake for children was $0.29 \mu \mathrm{g} / \mathrm{kg}$ bodyweight/week, which is approximately $16 \%$ above the dietary references dose (RfD) in Hong Kong [12]. Furthermore, a recent Japanese cohort study suggested that prenatal methylmercury exposure affected neuronal function during child development $[13,14]$.

Metallothionein (MT) is a defense factor against harmful metals such as mercury and cadmium. MT is a cysteine rich, low molecular protein that reduces toxicity by binding to metals $[15,16]$. There are four isoforms of MT, I to IV, which have different locations and levels of expression and varied physiological functions $[15,16]$. MT-III, which is present in the brain, has a protective effect against various brain diseases [17-19].

Recently, it has been reported that methylmercury increases the expression of several chemokine genes specific to the mouse brain [20]. Furthermore, we examined the impact of methylmercury on the expression of chemokine genes in various mouse tissues and found that expression of Ccl4 shows brain specific induction by methylmercury treatment [21]. Chemokines are a type of cytokine known to cause migration of leukocytes. They are secreted primarily from immune cells and participate in the inflammatory response [22]. Chemokines are also secreted from various tissues, including the brain, kidney, and liver [23-26].

In this study, we investigated the involvement of MT-III in chemokine gene expression in the cerebrum and cerebellum in response to methylmercury and mercury vapor using the MT-III null mice.

\section{Materials and Methods}

\subsection{Animals and Exposure Procedures}

MT-III null mice and 129/Sv mice as wild-type controls were purchased from The Jackson Laboratory (Bar Harbor, ME, USA) and routinely bred in the vivarium of the School of Pharmacy, Aichi Gakuin University. MT-III null mice were engineered by Erickson et al. [18] and had the 129/Sv genetic background. Three-week-old female mice were caged in a ventilated animal room at $24{ }^{\circ} \mathrm{C} \pm 1{ }^{\circ} \mathrm{C}$ with $50 \pm 10 \%$ relative humidity, and a $12 \mathrm{~h}$ light-dark cycle in the animal room of the School of Pharmacy, Aichi Gakuin University. Mice were maintained on standard laboratory food (MF, Oriental Yeast Co., Tokyo, Japan) and tap water ad libitum, and they received humane care throughout the experiment according to the guidelines of the School of Pharmacy.

Mice were assigned randomly to control or experimental groups $(n=4-5)$. For mercury vapor $\left(\mathrm{Hg}^{0}\right)$ exposure, mice were placed in a mercury vapor exposure chamber and exposed for $8 \mathrm{~h}$ every day at a mean concentration of 0.121 (range: 0.080 to 0.180 ) $\mathrm{mg} / \mathrm{m}^{3}$ for 4 weeks. The concentration of mercury in the exposure chamber was measured every day using a mercury survey meter (EMP-1A, Nippon Instruments Co., Tokyo, Japan). For methylmercury $\left(\mathrm{CH}_{3} \mathrm{Hg}^{+}\right)$exposure, methylmercury chloride (GL Sciences Inc., Tokyo, Japan) was diluted with distilled water to prepare a 5 ppm solution. The solution containing 5 ppm methylmercury was given ad libitum instead of tap water. After 4 weeks of exposure, the cerebrum and cerebellum were removed from each mouse under ether anesthesia.

\subsection{Real-Time Reverse Transcription-Polymerase Chain Reaction (RT-PCR)}

Total RNA was extracted from brain tissues using TRIzol ${ }^{\circledR}$ Reagent (Ambion, Grand Island, NY, USA) according to the manufacturer's instructions. Total RNA was incubated with a PrimeScript ${ }^{\mathrm{TM}}$ RT Reagent Kit (Perfect Real Time) (TaKaRa Bio, Shiga, Japan) to generate cDNA. Real time PCR was performed using SYBR Premix Ex Taq ${ }^{\mathrm{TM}}$ II (Perfect Real Time) (TaKaRa Bio) and a Thermal Cycler Dice Real time system (TaKaRa Bio). PCR conditions were: $10 \mathrm{~s}$ of hot start at $95{ }^{\circ} \mathrm{C}$ followed by 40 cycles of $5 \mathrm{~s}$ at $95^{\circ} \mathrm{C}$ and $30 \mathrm{~s}$ at $60^{\circ} \mathrm{C}$. Gene expression was normalized to $\beta$-actin mRNA levels. Oligonucleotide sequences of the primers (sense and antisense, respectively) were: 5'-TCTAAGCGTCACCACGACTTCA-3' and 5'-GTGCACTTGCAGTTCTTGCAG-3' for the mouse MT-I gene; $5^{\prime}$-CCTGCAATGCAAACAACAATGC- $3^{\prime}$ and $5^{\prime}$-AGCTGCACTTGTCGGAAGC- $3^{\prime}$ for the 


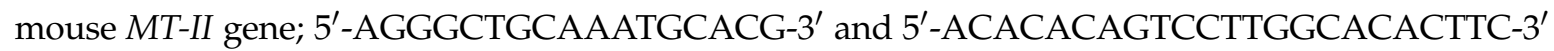
for the mouse MT-III gene; 5'-ATGAAGGTCTCCACCACTGC-3' and $5^{\prime}$-CCCAGGTCTCTTTGG AGTCA-3' for the mouse $C c l 3$ gene; $5^{\prime}$-CAAACCTAACCCCGAGCAACAC- $3^{\prime}$ and $5^{\prime}$-GGTCTCATA GTAATCCATCACAAAGC-3' for the mouse $C c l 4$ gene; $5^{\prime}$-AATGCATCCACATGCTGCTA-3 ${ }^{\prime}$ and $5^{\prime}$-CTTTGGAGTTGGGGTTTTCA- $3^{\prime}$ for the mouse $C c l 7$ gene; $5^{\prime}$-GTCCTCAAGGTATTGGCTGGA- $3^{\prime}$ and $5^{\prime}$-GGGTCAGCACAGATCTCCTT-3' for the mouse $C c l 12$ gene; $5^{\prime}$-AAGTGCTGCCGTCATTTTCT- $3^{\prime}$ and $5^{\prime}$-GTGGCAATGATCTCAACACG- $3^{\prime}$ for the mouse $C x c 110$ gene; $5^{\prime}$-CCTAAGGCCAACCGTGAAAA- $3^{\prime}$ and $5^{\prime}$-AGGCATACAGGGACAGCACA- $3^{\prime}$ for the mouse $\beta$-actin gene.

\subsection{Analysis of Mercury Concentrations in Tissues}

Mercury concentrations in tissues were measured with a cold vapor atomic absorption spectrophotometer (RA-3 Mercury Analyzer; Nippon Instruments, Tokyo, Japan) after digestion with a concentrated acid mixture $\left[\mathrm{HNO}_{3} / \mathrm{HClO}_{4} 1: 3(v / v)\right]$.

\subsection{Statistical Analyses}

Statistical analyses were undertaken using single factor ANOVA followed by Bonferroni's test for post hoc comparison $(P<0.05)$.

\section{Results}

\subsection{Body Weight Changes}

Body weights of the MT-III null mice and wild-type mice were measured one day after completion of exposure. The body weights of wild-type mice and MT-III null mice exposed to methylmercury were similar to those of the corresponding control mice (Figure 1). The body weights of wild-type mice and MT-III null mice exposed to mercury vapor were significantly lower than those of the corresponding control mice (Figure 1). However, there was no difference in body weight fluctuation in response to mercury exposure between wild-type mice and MT-III null mice (Figure 1).

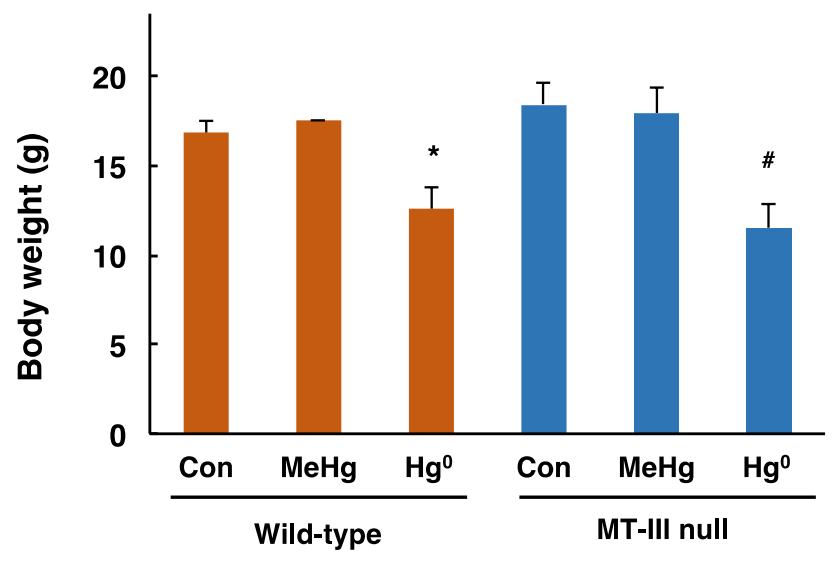

Figure 1. Body weights of the wild-type and MT-III null mice exposed to mercury compounds. Body weights of the wild-type and MT-III null mice were measured one day after the final mercury exposure. Values are the mean \pm S.D. $(n=4-5)$ * Significantly different from the control group of wild-type mice, $P<0.05$. \# Significantly different from the control group of MT-III null mice, $P<0.05$.

\subsection{Total Mercury Concentrations in the Cerebrum and Cerebellum}

The total mercury levels in the cerebrum and cerebellum of mice exposed to methylmercury or mercury vapor are shown in Figure 2. In the cerebrum of wild-type mice, mercury concentrations of $2380.57 \pm 300.24 \mathrm{ng} / \mathrm{g}$ tissue and $519.99 \pm 13.68 \mathrm{ng} / \mathrm{g}$ tissue were detected after methylmercury exposure and mercury vapor exposure, respectively (Figure 2A). In the cerebrum of MT-III null mice, 
mercury concentrations of $2373.14 \pm 957.12 \mathrm{ng} / \mathrm{g}$ tissue and $475.79 \pm 56.73 \mathrm{ng} / \mathrm{g}$ tissue were detected after methylmercury exposure and mercury vapor exposure, respectively (Figure 2A). In the cerebellum of wild-type mice, mercury concentrations of $1715.23 \pm 121.09 \mathrm{ng} / \mathrm{g}$ tissue and $783.58 \pm 44.15 \mathrm{ng} / \mathrm{g}$ tissue were detected following methylmercury exposure and mercury vapor exposure, respectively (Figure 2B). In the cerebellum of MT-III null mice, mercury concentrations of $1643.18 \pm 130.82 \mathrm{ng} / \mathrm{g}$ tissue and $779.71 \pm 54.85 \mathrm{ng} / \mathrm{g}$ tissue were detected in response to methylmercury exposure and mercury vapor exposure, respectively (Figure 2B). However, no significant difference was observed between wild-type mice and MT-III null mice in either the cerebrum or cerebellum (Figure 2).

A

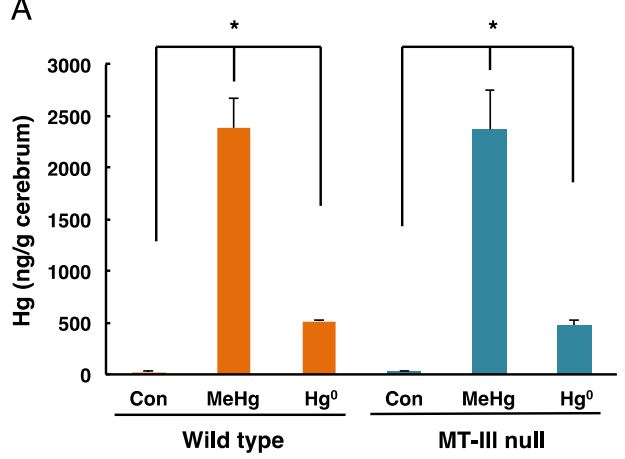

B

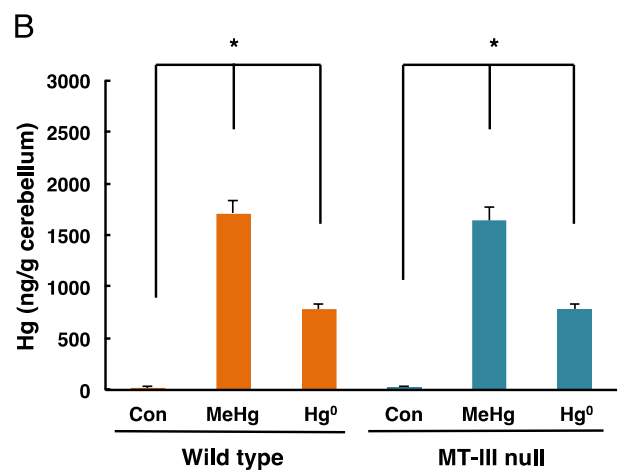

Figure 2. Mercury concentrations in the cerebrum and cerebellum of wild-type mice and MT-III null mice exposed to mercury compounds. Cerebra and cerebella were removed one day after the final mercury exposure. Total mercury levels in the cerebrum (A) and cerebellum (B) were measured. Values are the mean \pm S.D. $(\mathrm{n}=4-5) .{ }^{*} P<0.05$.

\subsection{The Levels of MT-I, MT-II, MT-III mRNAs in the Cerebrum and Cerebellum after Mercury Exposure}

The mRNA levels of MT-I in the cerebrum were significantly increased only in the wild-type mice exposed to methylmercury (Figure 3A). The mRNA levels of MT-II in the cerebrum were significantly decreased only in MT-III null mice exposed to mercury vapor (Figure 3B). The MT-III mRNA levels in the cerebrum of wild-type mice were not altered by methylmercury or mercury vapor exposure (Figure 3C).

A

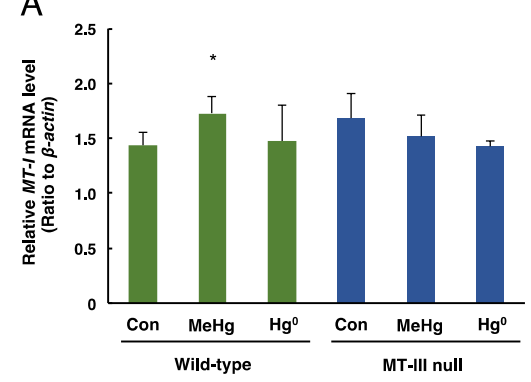

B

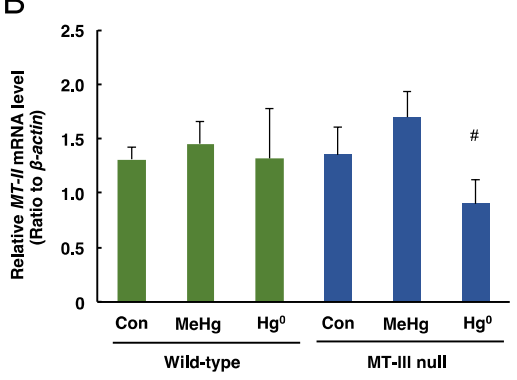

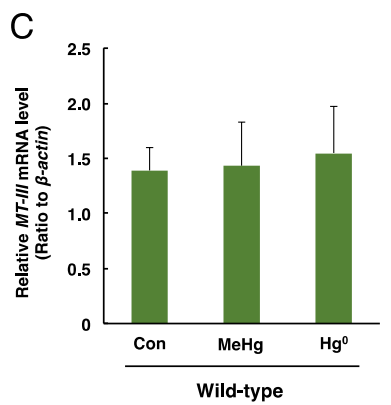

Figure 3. The levels of MT-I, MT-II and MT-III mRNAs in the cerebra of wild-type mice and MT-III null mice exposed to mercury compounds. mRNA levels of MT-I (A), MT-II (B) and MT-III (C) were determined by real time RT-PCR. mRNA levels were normalized with $\beta$-actin. Values are the mean \pm S.D. $(n=4-5)$. ${ }^{*}$ Significantly different from the control group of wild-type mice, $P<0.05$.

\# Significantly different from the control group of MT-III null mice, $P<0.05$.

The mRNA levels of MT-I, MT-II and MT-III in the cerebellum of each exposed group are shown in Figure 4. MT-I mRNA levels in the cerebellum were not changed by mercury exposure in either wild-type mice or MT-III null mice (Figure 4A). The mRNA levels of MT-II in the cerebellum were significantly decreased only in the wild-type mice exposed to methylmercury (Figure 4B). No changes 
in MT-III mRNA levels were observed in the wild-type mice exposed to methylmercury or mercury vapor (Figure 4C). These results indicate that MT-III does not affect the accumulation of mercury after methylmercury or mercury vapor exposure.
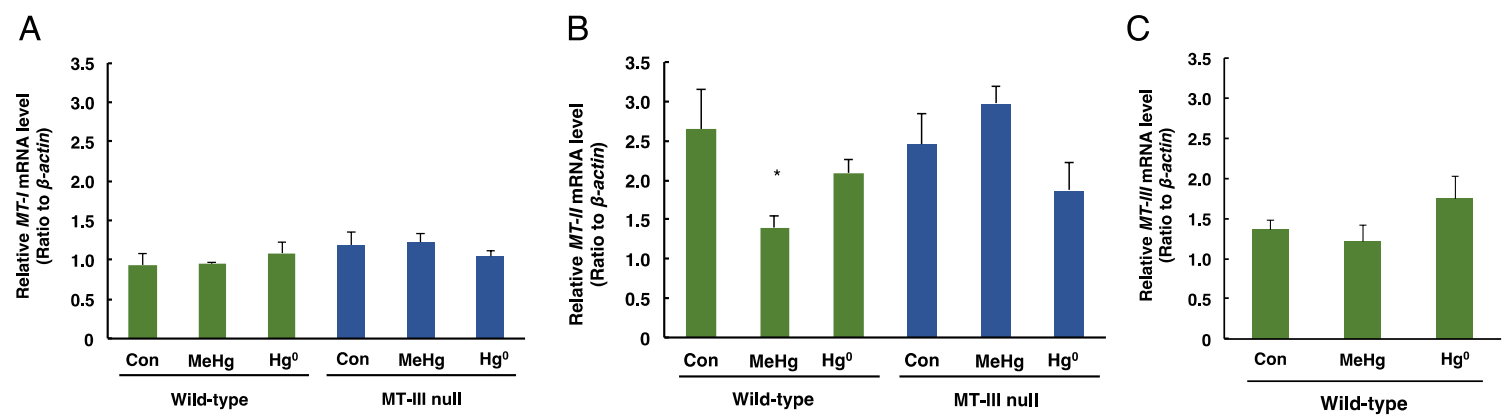

Figure 4. The levels of MT-I, MT-II and MT-III mRNAs in the cerebella of wild-type mice and MT-III null mice exposed to mercury compounds. mRNA levels of MT-I (A), MT-II (B) and MT-III (C) were determined by real time RT-PCR. mRNA levels were normalized with $\beta$-actin. Values are the mean \pm S.D. $(n=4-5)$. * Significantly different from the control group of wild-type mice, $P<0.05$.

\subsection{Changes in Expression of Chemokine Genes in the Cerebrum in Response to Mercury Exposure}

Ccl3 mRNA levels in the cerebrum were significantly increased by methylmercury exposure only in the MT-III null mice (Figure 5A). Moreover, Ccl3 mRNA levels in the cerebrum of MT-III null mice were higher than those of wild-type mice by methylmercury exposure (Figure 5A). Ccl4 mRNA levels did not change after mercury exposure (Figure 5B). Ccl7 mRNA levels were markedly elevated in the MT-III null mice and wild-type mice after methylmercury and mercury vapor exposure (Figure 5C). Although Ccl12 mRNA levels were increased by MT-III deficiency, methylmercury exposure increased Ccl12 mRNA levels only in the wild-type mice (Figure 5D). Cxcl10 mRNA levels were significantly elevated only when the wild-type mice were exposed to methylmercury (Figure 5E).
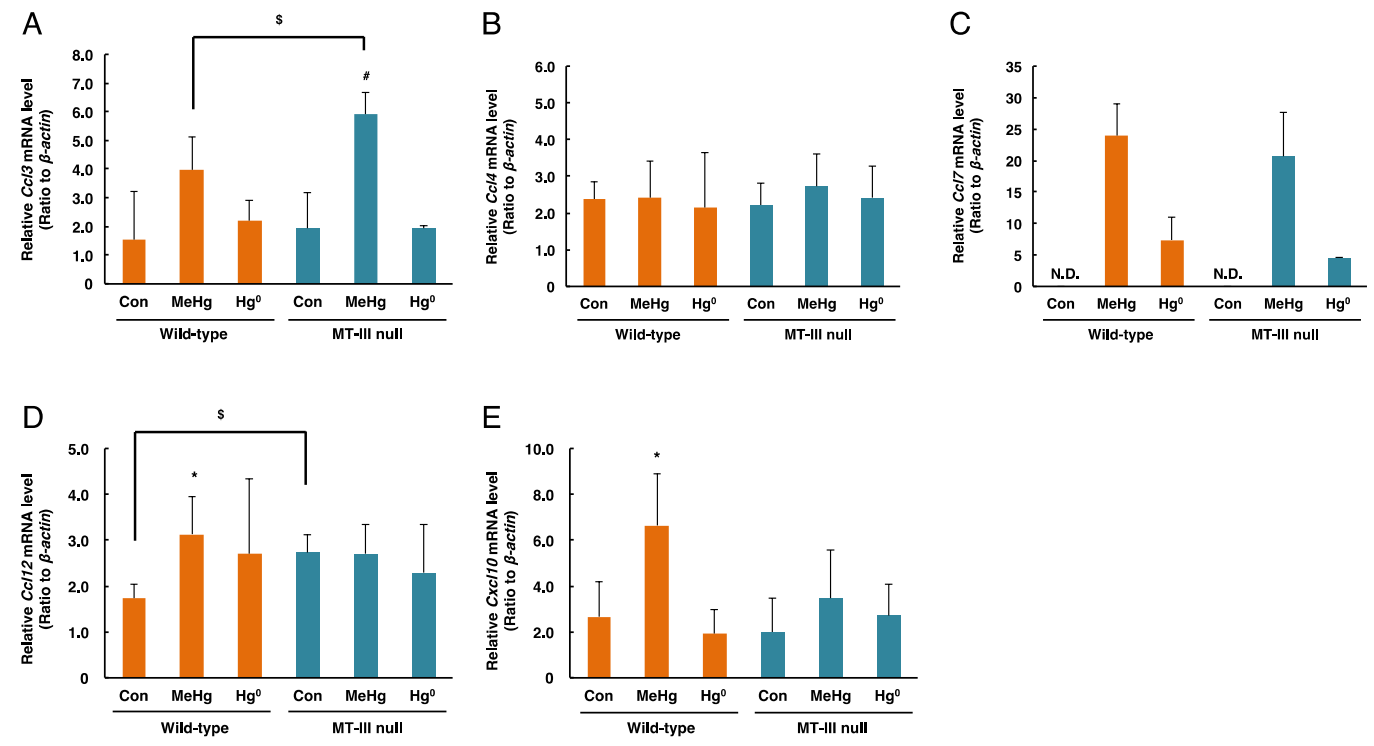

Figure 5. mRNA levels of chemokine genes in the cerebra of wild-type mice and MT-III null mice exposed to mercury compounds. mRNA levels of Ccl3 (A), Ccl4 (B), Ccl7 (C), Ccl12 (D) and Cxcl10 (E) were determined by real-time RT-PCR. mRNA levels were normalized with $\beta$-actin. Values are the mean \pm S.D. $(n=4-5)$. ${ }^{*}$ Significantly different from the control group of wild-type mice, $P<0.05$. \# Significantly different from the control group of MT-III null mice, $P<0.05$. ${ }^{\$}$ Significantly different between wild-type and MT-III null mice, $P<0.05$. 


\subsection{Changes in Expression of Chemokine Genes in the Cerebellum after Mercury Exposure}

The mRNA levels of $\mathrm{Ccl} 3$ in the cerebellum were significantly increased by methylmercury in the MT-III null mice and wild-type mice, and mercury vapor significantly increased Ccl3 mRNA levels only in the wild-type mice (Figure 6A). Ccl4 mRNA levels were significantly increased by methylmercury in the MT-III null mice and wild-type mice (Figure 6B). $\mathrm{Ccl} 7 \mathrm{mRNA}$ levels were significantly increased by methylmercury in the MT-III null mice and wild-type mice, and were significantly increased only in the MT-III null mice in response to mercury vapor (Figure 6C). Ccl12 mRNA levels were significantly increased by both methylmercury and mercury vapor in the MT-III null mice and wild-type mice (Figure 6D). However, Ccl12 mRNA levels in the MT-III null mice exposed to methylmercury were lower than those of wild-type mice (Figure 6D). Cxcl10 mRNA levels were significantly elevated only when the MT-III null mice were exposed to methylmercury (Figure 6E).

A
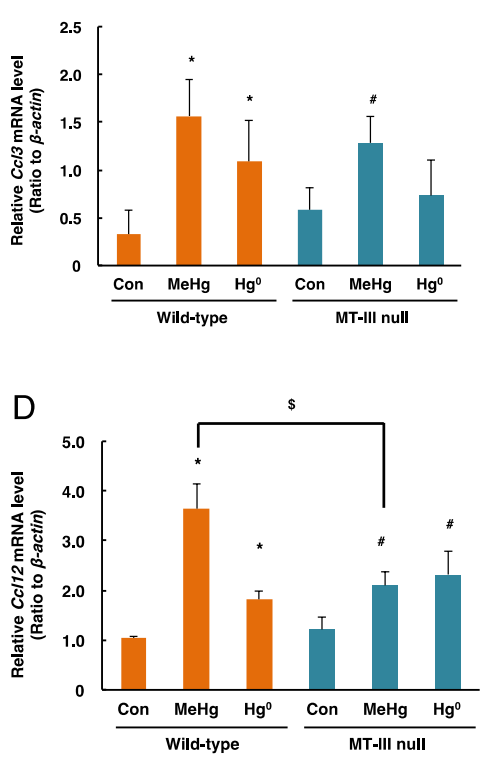

B

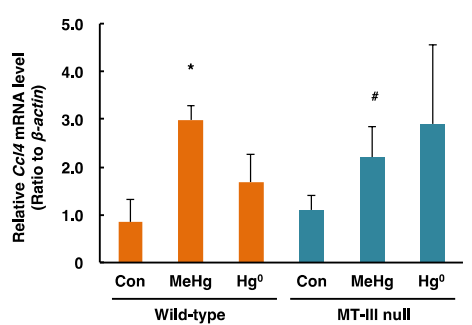

$\mathrm{E}$

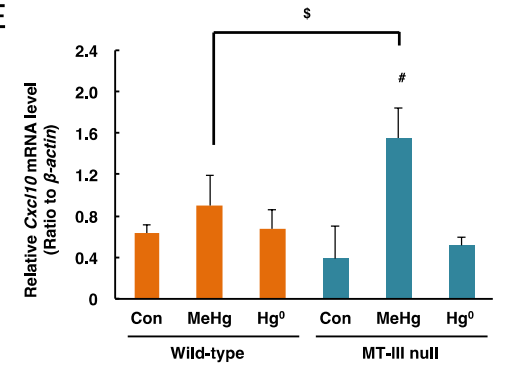

C

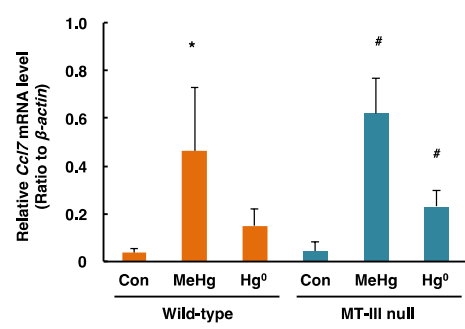

Figure 6. mRNA levels of chemokine genes in the cerebella of wild-type mice and MT-III null mice exposed to mercury compounds. mRNA levels of Ccl3 (A), Ccl4 (B), Ccl7 (C), Ccl12 (D) and Cxcl10 (E) were determined by real-time RT-PCR. mRNA levels were normalized with $\beta$-actin. Values are the mean \pm S.D. $(\mathrm{n}=4-5)$. * Significantly different from the control group of wild-type mice, $P<0.05$. \# Significantly different from the control group of MT-III null mice, $P<0.05 .{ }^{\$}$ Significantly different between wild-type and MT-III null mice, $P<0.05$.

\section{Discussion}

MT-III is highly expressed in neurons [17], and also shows a protective effect against brain diseases $[18,19]$. Mercury compounds, such as methylmercury and mercury vapor, are harmful substances that cause disorders of the CNS, but the influence of MT-III on the disorders caused by these mercuric compounds is poorly understood. Recently, methylmercury has been reported to increase expression of the chemokine genes, Ccl3, Ccl4, Ccl7, Ccl12 and Cxcl10 in the mouse brain [20,21,27]. The most highlighted knowledge in this study is that $\mathrm{Ccl} 3$ expression in the cerebrum and the cerebellar expression of $\mathrm{Ccl12}$ and $\mathrm{Cxcl10}$ were significantly different between wild-type mice and MT-III null mice only in the methylmercury exposure. MT-III is abundantly expressed in the normal brain; on the other hand, in a brain with Alzheimer's disease, MT-III expression is largely reduced [17]. It was suggested that MT-III might have a protective role in cerebral ischemia [28]. Furthermore, inflammatory factors are upregulated upon the brain damage, as it increases phagocytosis and the release of inflammatory mediators $[29,30]$. The present study suggests that the increase in chemokine expression 
may be involved in methylmercury-triggered brain damage with topical specificity. The present study also suggest that MT-III may be the cause of the difference in inflammatory response upon methylmercury exposure.

Our present study revealed that the MT-III deficiency had no effect on mercury concentration in the brains of mice exposed to mercury compounds; however, the MT-III deficiency influenced the expression of chemokine genes in response to mercury exposure. The expression of Ccl12 and Cxcl10 in the cerebrum was increased in the wild-type mice by methylmercury; but not in the cerebrum of MT-III null mice. Moreover, in response to mercury vapor exposure, $\mathrm{Ccl} 3$ expression in the cerebellum was not changed in the MT-III null mice, but was significantly elevated in the wild-type mice. In the cerebellum of wild-type mice, the expression of $\mathrm{Ccl} 7$ was not changed by mercury vapor exposure and that of $\mathrm{Cxcl10}$ was not changed by methylmercury exposure; however, they were significantly elevated in the MT-III null mice. Indeed, the fluctuation in Cxcl10 expression in response to methylmercury was observed in the cerebrum of wild-type mice, and in the cerebellum of MT-III null mice. Taken together, these findings indicate that MT-III may affect the expression of some chemokine genes in response to different mercury compounds differently in the cerebrum and cerebellum. In recent years, MT-I and MT-II have been reported to be involved in inflammatory reactions in cardiomyocytes [31]. The present study indicates that MT-III may be involved in inflammatory reactions consequent to an exogenous stress on the brain.

Chemokines are associated with inflammatory damage in a number of tissues, including the brain [23-26]. Chemokines may function as signaling molecules in the CNS [32]. Accordingly, the expression of several chemokines increases with hypoglossal nerve damage, however the role of chemokines in cranial nerves remains unclear. Methylmercury induces a brain-specific increase in $\mathrm{Ccl} 4$ expression in mice [21]. In addition, it is assumed that CCL4 is involved in the pathway mediating the toxicity of methylmercury in the CNS [33,34]. In this study, methylmercury induced Ccl4 gene expression in the cerebellum not only in the wild-type mice but also in the MT-III null mice. Therefore, CCL4 may be an important factor mediating methylmercury toxicity.

Previous studies revealed that postnatal mice exposed to $0.188 \mathrm{mg} / \mathrm{m}^{3}$ mercury vapor or $3.85 \mathrm{ppm}$ methylmercury showed a decrease in total locomotive activity in the OPF [35]. In this study, we exposed the mice to similar doses of mercury compounds. Because several chemokine gene expressions were increased in brain tissues of wild-type mice, chemokine genes may be associated with the influence of mercury exposure in childhood on neuronal development.

MT-I/II null mice showed an enhanced adverse effect of neonatal mercury $\left(\mathrm{HgCl}_{2}\right)$ exposure [19]. Moreover, MT-I/II null mice exposed to mercury vapor showed decreased locomotor activity [36,37]. Furthermore, the highly sensitive methylmercury toxicity in MT-I/II deficient astrocytes was rescued by the introduction of the MT-I gene [38]. Thus, MT-I and MT-II were suggested to be involved in mercury compound induced neuropathy, but the role of MT-III in neuropathy caused by mercury compounds is almost unknown. Our present study revealed that MT-III deficiency is involved in mercury-induced neuropathy through changing cerebral chemokine gene expression.

Author Contributions: J.-Y.L. conducted experiments, analyzed the data and wrote the manuscript. M.T. analyzed the gene expression of metallothioneins. G.-W.H., M.-S.K., T.T., and A.N. analyzed gene expression of chemokines. M.Y. supported mercury exposure and mercury analyses. M.S. managed the project and revised the manuscript.

Funding: This research was supported by a research grant from the Institute of Pharmaceutical Life Sciences, Aichi Gakuin University.

Acknowledgments: We sincerely thank Ryutaro Kimata for excellent experimental support.

Conflicts of Interest: The authors declare no conflicts of interest.

\section{References}

1. Lee, J.Y.; Ishida, Y.; Kuge, S.; Naganuma, A.; Hwang, G.W. Identification of substrates of F-box protein involved in methylmercury toxicity in yeast cells. FEBS Lett. 2015, 589, 2720-2725. [CrossRef] [PubMed] 
2. Lee, J.Y.; Ishida, Y.; Takahashi, T.; Naganuma, A.; Hwang, G.W. Transport of pyruvate into mitochondria is involved in methylmercury toxicity. Sci. Rep. 2016, 6, 21528. [CrossRef] [PubMed]

3. Tokumoto, M.; Lee, J.Y.; Shimada, A.; Tohyama, C.; Satoh, M. Glutathione has a more important role than metallothionein-I/II against inorganic mercury-induced acute renal toxicity. J. Toxicol. Sci. 2018, 43, 275-280. [CrossRef] [PubMed]

4. Mori, N.; Yasutake, A.; Marumoto, M.; Hirayama, K. Methylmercury inhibits electron transport chain activity and induces cytochrome c release in cerebellum mitochondria. J. Toxicol. Sci. 2011, 36, 253-259. [CrossRef] [PubMed]

5. Watanabe, J.; Nakamachi, T.; Ogawa, T.; Naganuma, A.; Nakamura, M.; Shioda, S.; Nakajo, S. Characterization of antioxidant protection of cultured neural progenitor cells (NPC) against methylmercury (MeHg) toxicity. J. Toxicol. Sci. 2009, 34, 315-325. [CrossRef] [PubMed]

6. Grandjean, P.; Weihe, P.; Jørgensen, P.J.; Clarkson, T.; Cernichiari, E.; Viderø, T. Impact of maternal seafood diet on fetal exposure to mercury, selenium, and lead. Arch. Environ. Health 1992, 47, 185-195. [CrossRef] [PubMed]

7. Grandjean, P.; Weihe, P.; White, R.F.; Debes, F.; Araki, S.; Yokoyama, K.; Murata, K.; Sørensen, N.; Dahl, R.; Jørgensen, P.J. Cognitive deficit in 7-year-old children with prenatal exposure to methylmercury. Neurotoxicol. Teratol. 1997, 19, 417-428. [CrossRef]

8. Hinton, J.J.; Veiga, M.M.; Veiga, A.T.C. Clean artisanal gold mining: A utopian approach? J. Clean. Prod. 2003, 11, 99-115. [CrossRef]

9. Veiga, M.M.; Maxson, P.A.; Hylander, L.D. Origin and consumption of mercury in small-scale gold mining. J. Clean. Prod. 2006, 14, 436-447. [CrossRef]

10. Bose-O'Reilly, S.; Lettmeier, B.; Gothe, R.M.; Beinhoff, C.; Siebert, U.; Drasch, G. Mercury as a serious health hazard for children in gold mining areas. Environ. Res. 2008, 107, 89-97. [CrossRef] [PubMed]

11. Li, P.; Feng, X.; Qiu, G.; Shang, L.; Wang, S. Mercury exposure in the population from Wuchuan mercury mining area, Guizhou, China. Sci. Total Environ. 2008, 395, 72-79. [CrossRef] [PubMed]

12. Chan, P.H.Y.; Chan, M.H.M.; Li, A.M.; Cheung, R.C.K.; Yu, X.T.; Lam, H.S. Methylmercury levels in commonly consumed fish and methylmercury exposure of children and women of childbearing age in Hong Kong, a high fish consumption community. Environ. Res. 2018, 166, 418-426. [CrossRef] [PubMed]

13. Suzuki, K.; Nakai, K.; Sugawara, T.; Nakamura, T.; Ohba, T.; Shimada, M.; Hosokawa, T.; Okamura, K.; Sakai, T.; Kurokawa, N.; et al. Neurobehavioral effects of prenatal exposure to methylmercury and pcbs, and seafood intake: Neonatal behavioral assessment scale results of tohoku study of child development. Environ. Res. 2010, 110, 699-704. [CrossRef] [PubMed]

14. Tatsuta, N.; Murata, K.; Iwai-Shimada, M.; Yaginuma-Sakurai, K.; Satoh, H.; Nakai, K. Psychomotor ability in children prenatally exposed to methylmercury: The 18-month follow-up of tohoku study of child development. Tohoku J. Exp. Med. 2017, 242, 1-8. [CrossRef] [PubMed]

15. Klaassen, C.D.; Liu, J.; Choudhuri, S. Metallothionein: An intracellular protein to protect against cadmium toxicity. Annu. Rev. Pharmacol. Toxicol. 1999, 39, 267-294. [CrossRef] [PubMed]

16. Vašák, M.; Meloni, G. Chemistry and biology of mammalian metallothioneins. J. Biol. Inorg. Chem. 2011, 16, 1067-1078. [CrossRef] [PubMed]

17. Uchida, Y.; Takio, K.; Titani, K.; Thara, Y.; Tomonaga, M. The growth inhibitory factor that is deficient in the Alzheimer's disease brain is a 68 amino acid metallothionein-like protein. Neuron 1991, 7, 337-347. [CrossRef]

18. Erickson, J.C.; Hollopeter, G.; Thomas, S.A.; Froelick, G.J.; Palmiter, R.D. Disruption of the metallothionein-III gene in mice: Analysis of brain zinc, behavior, and neuron vulnerability to metals, aging, and seizures. J. Neurosci. 1997, 17, 1271-1281. [CrossRef] [PubMed]

19. West, A.K.; Hidalgo, J.; Eddins, D.; Levin, E.D.; Aschner, M. Metallothionein in the central nervous system: Roles in protection, regeneration and cognition. Neurotoxicology 2008, 29, 489-503. [CrossRef] [PubMed]

20. Hwang, G.W.; Lee, J.Y.; Ryoke, K.; Matsuyama, F.; Kim, J.M.; Takahashi, T.; Naganuma, A. Gene expression profiling using DNA microarray analysis of the cerebellum of mice treated with methylmercury. J. Toxicol. Sci. 2011, 36, 389-391. [CrossRef] [PubMed]

21. Lee, J.Y.; Hwang, G.W.; Kim, M.S.; Takahashi, T.; Naganuma, A. Methylmercury induces a brain-specific increase in chemokine CCL4 expression in mice. J. Toxicol. Sci. 2012, 37, 1279-1282. [CrossRef] [PubMed] 
22. Zlotnik, A.; Yoshie, O. Chemokines: A new classification system and their role in immunity. Immunity 2000, 12, 121-127. [CrossRef]

23. Gorter, J.A.; van Vliet, E.A.; Aronica, E.; Breit, T.; Rauwerda, H.; Lopes da Silva, F.H.; Wadman, W.J. Potential new antiepileptogenic targets indicated by microarray analysis in a rat model for temporal lobe epilepsy. J. Neurosci. 2006, 26, 11083-11110. [CrossRef] [PubMed]

24. Soria, G.; Ben-Baruch, A. The inflammatory chemokines CCL2 and CCL5 in breast cancer. Cancer Lett. 2008, 267, 271-285. [CrossRef] [PubMed]

25. Saiman, Y.; Friedman, S.L. The role of chemokines in acute liver injury. Front. Physiol. 2012, 3, 213. [CrossRef] [PubMed]

26. Shimizu, H.; Bolati, D.; Higashiyama, Y.; Nishijima, F.; Shimizu, K.; Niwa, T. Indoxyl sulfate upregulates renal expression of MCP-1 via production of ROS and activation of NF-kappaB, p53, ERK, and JNK in proximal tubular cells. Life Sci. 2012, 90, 525-530. [CrossRef] [PubMed]

27. Kim, M.S.; Takahashi, T.; Lee, J.Y.; Hwang, G.W.; Naganuma, A. Global chemokine expression in methylmercury-treated mice: Methylmercury induces brain-specific expression of CCL3 and CCL4. J. Toxicol. Sci. 2013, 38, 925-929. [CrossRef] [PubMed]

28. Koumura, A.; Hamanaka, J.; Shimazawa, M.; Honda, A.; Tsuruma, K.; Uchida, Y.; Hozumi, I.; Satoh, M.; Inuzuka, T.; Hara, H. Metallothionein-III knockout mice aggravates the neuronal damage after transient focal cerebral ischemia. Brain Res. 2009, 1292, 148-154. [CrossRef] [PubMed]

29. Poulsen, C.B.; Penkowa, M.; Borup, R.; Nielsen, F.C.; Cáceres, M.; Quintana, A.; Molinero, A.; Carrasco, J.; Giralt, M.; Hidalgo, J. Brain response to traumatic brain injury in wild-type and interleukin-6 knockout mice: A microarray analysis. J. Neurochem. 2005, 92, 417-432. [CrossRef] [PubMed]

30. Scuderi, C.; Stecca, C.; Iacomino, A.; Steardo, L. Role of astrocytes in major neurological disorders: The evidence and implications. IUBMB Life 2013, 65, 957-961. [CrossRef] [PubMed]

31. Duerr, G.D.; Dewald, D.; Schmitz, E.J.; Verfuerth, L.; Keppel, K.; Peigney, C.; Ghanem, A.; Welz, A.; Dewald, O. Metallothioneins 1 and 2 modulate inflammation and support remodeling in ischemic cardiomyopathy in mice. Mediat. Inflamm. 2016, 2016, 7174127. [CrossRef] [PubMed]

32. Gamo, K.; Kiryu-Seo, S.; Konishi, H.; Aoki, S.; Matsushima, K.; Wada, K.; Kiyama, H. G-protein-coupled receptor screen reveals a role for chemokine receptor CCR5 in suppressing microglial neurotoxicity. J. Neurosci. 2008, 28, 11980-11988. [CrossRef] [PubMed]

33. Adler, M.W.; Rogers, T.J. Are chemokines the third major system in the brain? J. Leukoc. Biol. 2005, 78, 1204-1209. [CrossRef] [PubMed]

34. Miller, R.J.; Rostene, W.; Apartis, E.; Banisadr, G.; Biber, K.; Milligan, E.D.; White, F.A.; Zhang, J. Chemokine action in the nervous system. J. Neurosci. 2008, 28, 11792-11795. [CrossRef] [PubMed]

35. Yoshida, M.; Lee, J.Y.; Satoh, M.; Watanabe, C. Neurobehavioral effects of postnatal exposure to low-level mercury vapor and/or methylmercury in mice. J. Toxicol. Sci. 2018, 43, 11-17. [CrossRef] [PubMed]

36. Yoshida, M.; Watanabe, C.; Horie, K.; Satoh, M.; Sawada, M.; Shimada, A. Neurobehavioral changes in metallothionein-null mice prenatally exposed to mercury vapor. Toxicol. Lett. 2005, 155, 361-368. [CrossRef] [PubMed]

37. Yoshida, M.; Watanabe, C.; Kishimoto, M.; Yasutake, A.; Satoh, M.; Sawada, M.; Akama, Y. Behavioral changes in metallothionein-null mice after the cessation of long-term, low-level exposure to mercury vapor. Toxicol. Lett. 2006, 161, 210-218. [CrossRef] [PubMed]

38. Yao, C.P.; Allen, J.W.; Mutkus, L.A.; Xu, S.B.; Tan, K.H.; Aschner, M. Foreign metallothionein-I expression by transient transfection in MT-I and MT-II null astrocytes confers increased protection against acute methylmercury cytotoxicity. Brain Res. 2000, 855, 32-38. [CrossRef]

(C) 2018 by the authors. Licensee MDPI, Basel, Switzerland. This article is an open access article distributed under the terms and conditions of the Creative Commons Attribution (CC BY) license (http:/ / creativecommons.org/licenses/by/4.0/). 